\title{
EFEKTIVITAS PENYIKATAN GIGI SECARA MANUAL DAN ELEKTRIK PADA GINGIVITIS RINGAN WANITA HAMIL TRIMESTER I
}

\author{
Yenita Alamsyah \\ Bagian Ortodonti, FKG, Universitas Baiturrahmah, Padang
}

\section{KATA KUNCI}

gingivitis, plak indeks, gingival indeks

\begin{abstract}
ABSTRAK
Wanita hamil umumnya mengutamakan kesehatan kehamilannya tetapi kurang memperhatikan pemeliharaan kesehatan gigi dan mulutnya. Wanita hamil biasanya mengalami perubahan perilaku terhadap pemeliharaan kesehatan gigi dan mulutnya. Untuk mencegah terjadinya gingivitis pada masa kehamilan dapat dilakukan kontrol plak secara efektif. Salah satu untuk mengurangi pertumbuhan plak yang dilakukan secara mekanis adalah dengan menggunakan sikat gigi.

Penelitian ini bertujuan untuk mengetahui efektivitas penyikatan gigi secara manual dan elektrik pada gingivitis ringan wanita hamil trimester I. Sampel pada penelitian ini adalah pasien wanita hamil trimester I berjumlah 20 orang terdiri dari dua kelompok, kelompok A dan kelompok B masing-masing 10 orang. Kelompok A dilakukan metode penyikatan secara manual dan kelompok B dengan sikat gigi elektrik. Dilakukan pengukuran Plak Indek (PI) dan Gingival Indek (GI).

Hasil penelitian menunjukkan bahwa pengukuran Plak Indek (PI) dan Gingival Indek (GI) baik dengan menggunakan sikat gigi manual maupun sikat gigi elektrik dengan uji t tidak terdapat perbedaan yang signifikan ( $\mathrm{p}>0.05)$.

Kesimpulan dari penelitian ini dengan sikat gigi manual akan sama efektifnya dengan sikat gigi elektrik dalam pembersihan plak jika digunakan secara benar.
\end{abstract}

\section{PENDAHULUAN}

Penyakit periodontal dikenal sebagai penyakit mulut yang paling utama di seluruh dunia. Radang gusi adalah bentuk yang paling ringan dari penyakit periodontal yang dapat dideteksi secara klinis. Proses terjadinya penyakit periodontal berjalan lambat, tapi progresif dan meluas dalam jangka waktu yang lama ${ }^{1}$.

Dua faktor etiologi penyakit periodontal yaitu faktor primer dan faktor skunder. Faktor primer yang mengakibatkan timbulnya penyakit periodontal berupa iritasi bakteri, sedangkan faktor lokal yang menjadi predisposisi dari akumulasi plak dan faktor sistemik $^{2}$. Salah satu faktor sistemik yang mempunyai pengaruh terhadap penyakit periodontal adalah kehamilan, yang disertai dengan perubahan keseimbangan hormonal ${ }^{3}$. Manifestasi klinis berupa perubahan ketidakseimbangan hormon dalam rongga mulut antara lain berupa gingivitis dengan tingkat keparahan yang bervariasi, mulai dari derajat ringat sampai berat. Faktor yang sering disebut sebagai faktor etiologi penyakit periodontal antara lain bakteri dan produknya, kalkulus, material alba dan food debris $^{2}$. 
Perubahan rongga mulut pada masa kehamilan selain disebabkan oleh perubahan hormonal juga berhubungan dengan keadaan kebersihan mulut ${ }^{4}$. Pada masa kehamilan, gingivitis dapat terjadi secara lokal atau menyeluruh. Kehamilan tidak menyebabkan gingivitis, tetapi metabolisme selama kehamilan meningkatkan respon iritasi lokal $^{5}$. Gingivitis pada masa kehamilan mempunyai kecenderungan untuk menjadi lebih parah dengan adanya iritasi lokal, sebanding dengan meningkatnya hormon seks. Meningkatnya sekresi hormon esterogen dan progesteron dalam darah mengakibatkan dilatasi pembuluh darah perifer dan meningkatnya permeabilitas vaskuler, sehingga mempermudah invasi bakteri ke dalam sulkus gingiva ${ }^{6}$. Namun apabila rongga mulut dipertahankan dalam keadaan bersih, gingivitis biasanya tidak akan timbul pada masa kehamilan. Seperti pada masa pubertas, inflamasi ringan akibat plak akan menjadi jauh lebih parah pada masa kehamilan ${ }^{2}$.

Wanita hamil umumnya mengutamakan kesehatan kehamilannya tetapi kurang memperhatikan pemeliharaan kesehatan gigi dan mulutnya. Wanita hamil biasanya mengalami perubahan perilaku terhadap pemeliharaan kesehatan gigi dan mulutnya. Perubahan pola perilaku ini cendrung mempermudah proses kerusakan gigi atau timbulnya penyakit gigi dan mulut. Pola perubahan sikap terhadap pemeliharaan kesehatan gigi dan mulut biasanya berupa kemalasan atau rasa tanggung jawab akan kesehatan gigi dan mulutnya menurun ${ }^{7}$. Untuk mencegah terjadinya gingivitis pada masa kehamilan dapat dilakukan kontrol plak secara efektif. Salah satu untuk mengurangi pertumbuhan plak yang dilakukan secara mekanis adalah dengan menggunakan sikat gigi ${ }^{8}$. Para dokter gigi setuju bahwa memperbaiki dan meggosok gigi secara benar merupakan prosedur penting untuk perawatan dan pencegahan gingivitis ringan ${ }^{9}$. Efektivitas menyikat gigi tergantung dari beberapa hal, yaitu bentuk sikat gigi, cara menyikat gigi dan frekwensi, serta lamanya menyikat gigi ${ }^{10}$. Sikat gigi dibedakan menjadi sikat gigi manual dan sikat gigi elektrik. Semenjak dimasyarakatkan, sebenarnya bentuk dasar sikat gigi ada 3 macam : (1) lurus, (2) konkaf dan (3) konveks yaitu antara pegangan dengan kepala sikat maupun bulu-bulu sikatnya sendiri dapat tidak membentuk sudut (lurus), membentuk satu atau dua sudut yang dapat menjadi konkaf atau konveks. Bentuk sikat gigi yang demikian disebut sebagai sikat gigi manual $^{11}$. Metode menyikat gigi yang dikenal di dunia Kedokteran Gigi pada prinsipnya terdapat enam pola dasar, yaitu (1) metode horizontal; (2) metode vertikal; (3) metode roll / berputar; (4) metode vibrasi / bergetar metode sirkular dan (6) metode fisilogis. Menstandarisasikan bahwa lama menyikat gigi yang efektif adalah 2 menit $^{12}$. Secara umum desain kepala sikat dan gerakan sikat gigi elektrik sama dengan sikat 
gigi manual ${ }^{12}$. Keuntungan penggunaan sikat gigi elektrik terutama adalah kemudahan yang dicapai dengan sikat tersebut. Pada individu tertentu sikat gigi elektrik memberikan beberapa keuntungan yaitu mampu mendorong anak-anak atau orang dewasa yang malas menjaga kebersihan mulutnya untuk menyikat gigi. Sikat gigi elektrik juga membantu individu yang cacat jasmaninya. Kebanyakan sikat gigi elektrik mempunyai kepala sikat yang relatif kecil memberikan keuntungan dalam menjangkau area sempit terutama permukaan lingual rahang bawah dimana kalkulus mudah terbentuk ${ }^{13}$.

Berdasarkan landasan teori dan pemikiran tersebut diatas maka timbul permasalahan : Apakah penyikatan gigi secara manual dan elektrik mempunyai efektivitas yang berbeda pada gingivitis ringan wanita hamil trimester I ?

\section{METODE PENELITIAN}

Jenis penelitian yang digunakan dalam penelitian ini adalah eksperimental dengan rancangan pretest-postest design ${ }^{14}$. Subjek penelitian adalah pasien wanita hamil trimester I berjumlah 20 orang terdiri dari dua kelompok, kelompok A 10 orang dan kelompok B 10 orang dengan kriteria pemilihan sampel :Wanita hamil trimester 1 , Gingivitis ringan (skor 0.1-1.0) setelah 1 minggu dilakukan scaling, Tidak menderita penyakit sistemik yang mempengaruhi status kesehatan gingiva, Tidak sedang mengkonsumsi obat antibiotik dan obat antiinflamasi

Bahan dan Alat Penelitian :

1. Alat Penelitian :

Alat diagnosa: kaca mulut, pinset dan sonde, Alat skeler dan polis, Sikat gigi manual, Sikat gigi elektrik, Neerbecken,Gelas kumur, Blanko pemeriksaan, Alat peraga (study model Rahang Atas dan Rahang Bawah)

\section{Bahan Penelitian :}

Kapas/ cotton roll, Bahan pewarna gigi (disclosing solution), Alkohol 70\%, Air, Pasta gigi

Subjek penelitian sebanyak 20 orang disiapkan sesuai dengan kriteria pemilihan sampel dan terlebih dahulu sudah diberi informasi yang cukup dan sudah menandatangani informed consent. Kemudian dilakukan pengukuran pertama indeks plak (PI) dan indeks gingiva (GI). Kemudian dilakukan scaling pada subjek penelitian untuk menyingkirkan plak dan kalkulus sehingga skor kebersihan mulutnya sama (nol). Satu minggu kemudian dilakukan pengukuran kedua PI dan GI dengan ketentuan skor 0.1-1.0 sesuai dengan kriteria sampel. Subjek penelitian dibagi menjadi 2 kelompok yaitu Kelompok A dan Kelompok $B$ masing-masing kelompok 10 orang. Kelompok A diinstruksikan menyikat gigi menggunakan sikat gigi manual metode berputar dan kelompok B diinstruksikan 
menyikat gigi menggunakan sikat gigi elektrik. Metode tersebut diajarkan pada subjek dengan memakai alat peraga (sikat gigi dan studi model rahang atas dan rahang bawah) agar lebih mudah dipahami dan subjek mengerti teknik sikat gigi serta waktu yang tepat untuk aktivitas tersebut. Kelompok A dan kelompok B menyikat gigi selama 10 hari, kemudian dilakukan pengukuran ketiga PI dan GI. Hasil pengukuran dimasukkan pada tabel kerja dan dihitung selisihnya.

Kriteria Plak Indeks ${ }^{2}$ :

\begin{tabular}{|c|c|c|}
\hline 0 & $=$ & Tidak ada plak \\
\hline 1 & $=$ & $\begin{array}{l}\text { Selapis tipis plak yang hanya dapat dilihat } \\
\text { dengan bantuan sonde atau discloting } \\
\text { solution. }\end{array}$ \\
\hline 2 & $=$ & $\begin{array}{l}\text { Akumulasi plak yang cukup banyak dan } \\
\text { dapat dilihat dengan mata telanjang. }\end{array}$ \\
\hline 3 & $=$ & $\begin{array}{l}\text { Akumulasi plak yang tebal dari bahan } \\
\text { lunak yang mengisi celah antara tepi } \\
\text { gingiva dan permukaan gigi. Regio } \\
\text { interdental terisi debris. }\end{array}$ \\
\hline \multicolumn{3}{|c|}{ Kriteria Gingival Indeks ${ }^{2}$} \\
\hline 0 & $=$ & Gingiva normal \\
\hline 1 & & $\begin{array}{l}\text { Inflamasi ringan, sedikit perubahan } \\
\text { warna, sedikit edema dan tidak terjadi } \\
\text { pendarahan saat palpasi }\end{array}$ \\
\hline 2 & & $\begin{array}{l}\text { Inflamasi sedang, warna kemerahan, } \\
\text { edema, mengkilat, terjadi pendarahan saat } \\
\text { probing }\end{array}$ \\
\hline 3 & $=$ & $\begin{array}{l}\text { Inflamasi parah, kemerahan dan edema, } \\
\text { ulserasi, cendrung terjadi pendarahan } \\
\text { spontan. }\end{array}$ \\
\hline
\end{tabular}

Analisis statistik untuk melihat perbedaan efektivitas penyikatan gigi secara manual dan elektrik pada gingivitis ringan wanita hamil trimester I digunakan analisa statistik t-test (uji t) ${ }^{14}$.

\section{HASIL PENELITIAN}

Hasil pemeriksaan dari skor GI dan PI di masukkan ke dalam blanko pemeriksaan yang telah disiapkan sebagai berikut :

Tabel 1. Tabel kerja hasil penilaian skor PI kelompok A (sikat gigi manual)

\begin{tabular}{ccccc}
\hline No & Identitas & \multicolumn{3}{c}{ Indeks Plak (PI) } \\
\cline { 3 - 5 } & subjek & $\begin{array}{c}\text { Pengukuran } \\
\text { Pengukuran }\end{array}$ & Selisih \\
\hline 1 & A1 & 2 & 3 & \\
2 & A2 & 1 & 1 & 1 \\
3 & A3 & 2 & 1 & 1 \\
4 & A4 & 1 & 1 & 0 \\
5 & A5 & 2 & 1 & 1 \\
6 & A6 & 1 & 0 & 1 \\
7 & A7 & 2 & 1 & 1 \\
8 & A8 & 2 & 2 & 0 \\
9 & A9 & 1 & 1 & 0 \\
10 & A10 & 2 & 0 & 2 \\
\cline { 3 - 5 } & & $\mathrm{X}=16$ & $\mathrm{X}=10$ & $\mathrm{X}=8$
\end{tabular}

Tabel 2. Tabel kerja hasil penilaian skor PI kelompok B (sikat gigi elektrik)

\begin{tabular}{ccccc}
\hline \multirow{2}{*}{ No } & Identitas & \multicolumn{3}{c}{ Indeks Plak (PI) } \\
\cline { 3 - 5 } & subjek & Pengukuran & $\begin{array}{c}\text { Pengukuran } \\
\text { Selisih }\end{array}$ \\
\hline 1 & B1 & 3 & 2 & 1 \\
2 & B2 & 2 & 2 & 0 \\
3 & B3 & 2 & 1 & 1 \\
4 & B4 & 1 & 1 & 0 \\
5 & B5 & 1 & 0 & 1 \\
6 & B6 & 1 & 1 & 0 \\
7 & B7 & 2 & 2 & 0 \\
8 & B8 & 2 & 1 & 1 \\
9 & B9 & 1 & 2 & 1 \\
10 & B10 & 2 & 1 & 1 \\
\cline { 3 - 5 } & & $\mathrm{X}=17$ & $\mathrm{X}=13$ & $\mathrm{X}=6$ \\
\hline
\end{tabular}

Tabel 3. Tabel kerja hasil penilaian skor GI kelompok A (sikat gigi manual)

\begin{tabular}{|c|c|c|c|c|}
\hline \multirow[b]{2}{*}{ No } & \multirow[b]{2}{*}{$\begin{array}{c}\text { Identitas } \\
\text { subjek }\end{array}$} & \multicolumn{3}{|c|}{ Indeks Gingiva (GI) } \\
\hline & & $\begin{array}{c}\text { Pengukuran } \\
2\end{array}$ & $\begin{array}{c}\text { Pengukuran } \\
3\end{array}$ & Selisih \\
\hline 1 & A1 & 2 & 2 & 0 \\
\hline 2 & $\mathrm{~A} 2$ & 2 & 1 & 1 \\
\hline 3 & A3 & 2 & 0 & 2 \\
\hline 4 & A4 & 1 & 1 & 1 \\
\hline 5 & A5 & 2 & 1 & 1 \\
\hline 6 & A6 & 1 & 2 & -1 \\
\hline 7 & A7 & 2 & 1 & 1 \\
\hline 8 & A8 & 2 & 1 & 1 \\
\hline 9 & A9 & 1 & 1 & 0 \\
\hline \multirow[t]{2}{*}{10} & A10 & 2 & 1 & 1 \\
\hline & & $\mathrm{X}=17$ & $\mathrm{X}=11$ & $\mathrm{X}=6$ \\
\hline
\end{tabular}


Tabel 4. Tabel kerja hasil penilaian skor GI kelompok B (sikat gigi elektrik)

\begin{tabular}{ccccc}
\hline No & $\begin{array}{c}\text { Identitas } \\
\text { subjek }\end{array}$ & \multicolumn{3}{c}{ Indeks Plak (PI) } \\
\cline { 3 - 5 } & & $\begin{array}{c}\text { Pengukuran } \\
\text { Pengukuran }\end{array}$ & Selisih \\
\hline 1 & B1 & 2 & 3 & \\
2 & B2 & 2 & 2 & 0 \\
3 & B3 & 2 & 0 & 1 \\
4 & B4 & 1 & 1 & 2 \\
5 & B5 & 2 & 1 & 0 \\
6 & B6 & 1 & 1 & 1 \\
7 & B7 & 1 & 0 & 0 \\
8 & B8 & 2 & 2 & 1 \\
9 & B9 & 2 & 1 & 0 \\
10 & B10 & 2 & 0 & 1 \\
& & $\mathrm{X}=17$ & $\mathrm{X}=11$ & $\mathrm{X}=8$
\end{tabular}

Hasil penelitian menunjukkan bahwa penilaian Plak Indek dengan menggunakan sikat gigi manual dan sikat gigi elektrik pada pengukuran 2 dan pengukuran 3 terlihat penurunan skor PI. Demikian juga dengan penilaian Gingiva Indek dengan menggunakan sikat gigi manual dan sikat gigi elektrik pada pengukuran 2 dan pengukuran 3 juga terlihat penurunan skor GI.

Untuk menguji ada tidaknya perbedaan efektivitas penyikatan gigi secara manual dan elektrik pada gingivitis ringan wanita hamil trimester I digunakan analisa statistik t-test (uji t) pada penilaian Plak Indek yang hasilnya terlihat pada tabel 5 .

Tabel 5. Hasil Uji t pada penilaian Plak Indek

\begin{tabular}{cc}
\hline & Perbedaan \\
\hline Sig (2-tailed) & 0.571 \\
Derajat Kebebasan & 18 \\
Probabilitas & 0.064 \\
& $(\mathrm{P}>0.05)$ \\
\hline
\end{tabular}

Berdasarkan uji t pada tabel 5 tersebut tidak terdapat perbedaan yang bermakna terhadap efektivitas penyikatan gigi secara manual dan elektrik pada gingivitis ringan wanita dengan penilaian Plak Indek.

Selanjutnya untuk menguji ada tidaknya perbedaan efektivitas penyikatan gigi secara manual dan elektrik pada gingivitis ringan wanita hamil trimester I digunakan analisa statistik t-test (uji t) pada penilaian Gingiva Indek yang hasilnya terlihat pada tabel 6 .

Tabel 6. Hasil Uji t pada penilaian Gingiva Indek

\begin{tabular}{cc}
\hline & Perbedaan \\
\hline Sig (2-tailed) & 1.000 \\
Derajat Kebebasan & 18 \\
Probabilitas & 0.062 \\
& $(\mathrm{P}>0.05)$ \\
\hline
\end{tabular}

Berdasarkan uji t pada tabel 6 tersebut juga tidak terdapat perbedaan yang bermakna terhadap efektivitas penyikatan gigi secara manual dan elektrik pada gingivitis ringan wanita dengan penilaian Gingiva Indek.

\section{PEMBAHASAN}

Hasil penelitian menunjukkan tidak terdapatnya perbedaan efektivitas penyikatan gigi secara manual dan elektrik pada gingivitis ringan wanita baik pada penilaian dengan Plak Indek dan Gingiva Indek. Hal ini menunjukkan bahwa jika penggunaan sikat gigi manual maupun elektrik dapat dilakukan dengan baik dan benar oleh individunya akan memberikan efek yang sama. Hal ini sesuai dengan pendapat ${ }^{10}$ yang mengatakan bahwa tidak ada perbedaan efektifitas yang bermakna antara sikat gigi manual dengan sikat gigi elektrik. 
Proses kehamilan menyebabkan perubahanperubahan fisiologis termasuk dirongga mulut. Perubahan dirongga mulut dipengaruhi oleh sistem hormonal bersamaan dengan faktor iritasi lokal didalam rongga mulut. Pada masa kehamilan, gingivitis dapat terjadi secara lokal atau menyeluruh. Kehamilan tidak menyebabkan gingivitis, tetapi metabolisme selama kehamilan meningkatkan respon iritasi lokal ${ }^{5}$. Gingivitis pada masa kehamilan mempunyai kecenderungan untuk menjadi lebih parah dengan adanya iritasi lokal, sebanding dengan meningkatnya hormon seks. Meningkatnya sekresi hormon esterogen dan progesteron dalam darah mengakibatkan dilatasi pembuluh darah perifer dan meningkatnya permeabilitas vaskuler, sehingga mempermudah invasi bakteri ke dalam sulkus gingiva ${ }^{6}$. Namun apabila rongga mulut dipertahankan dalam keadaan bersih, gingivitis biasanya tidak akan timbul pada masa kehamilan.Untuk mencegah timbulnya gangguan di rongga mulut selama masa kehamilan, perlu diciptakan kebersihan mulut yang optimal. Keperluan akan pemeliharaan kesehatan gigi dan mulut pada masa kehamilan perlu diperhatikan. Adanya pendarahan dan pembengkakan gingiva akan menimbulkan gangguan terutama pada waktu makan'. Pelaksanaan program kontrol plak penting dilakukan untuk mencegah peradangan pada gingiva akibat dari iritasi lokal, gangguan keseimbangan hormonal dan kelainan-kelainan lain selama kehamilan.
Dalam pemeliharaan kesehatan gigi dan mulut pada ibu hamil dilakukan penyikatan gigi dengan menggunakan sikat gigi manual maupun elektrik akan memberikan hasil yang sama efeknya apabila dilakukan dengan teknik dan waktu yang tepat.

\section{KESIMPULAN}

Berdasarkan hasil penelitian tentang perbedaan efektivitas penyikatan gigi secara manual dan elektrik pada gingivitis ringan wanita hamil trimester I maka dapat disimpulkan :

1. Pengukuran Indeks Plak (PI) pada gingivitis ringan wanita hamil trimester I dengan penyikatan gigi secara manual dan elektrik cendrung mengalami penurunan pada pengukuran 2 dan 3 .

2. Pengukuran Indeks Gingiva (GI) pada gingivitis ringan wanita hamil trimester I dengan penyikatan gigi secara manual dan elektrik cendrung mengalami penurunan pada pengukuran 2 dan 3 .

3. Penggunaan sikat gigi elektrik sama efektifnya dengan sikat gigi manual jika teknik penyikatan digunakan dengan benar.

\section{SARAN}

Berdasarkan hasil penelitian yang telah dilakukan, maka dapat diajukan saran sebagai berikut :

1. Perlu dilakukan penelitian lebih lanjut mengenai efektivitas penyikatan gigi secara manual dan elektrik pada 
gingivitis ringan wanita hamil trimester I dengan menggunakan metode penyikatan kombinasi sikat gigi manual, dental flos, sikat interdental dan tusuk gigi.

2. Di masa yang akan datang diharapkan dapat menjadi dasar ilmiah pemikiran dalam melihat perbedaan efektivitas penyikatan gigi secara manual dan elektrik pada gingivitis ringan wanita hamil trimester I untuk melakukan penyempurnaan dengan mengkaji pada populasi sampel yang lebih besar.

\section{DAFTAR PUSTAKA}

1. Goldman, H.M., Cohen, D.W., 2010., Periodontal Therapy, 9 nd ed., The C.V.Mosby Co., St Louis, Toronto, London

2. Manson, J.D., Eley, B.M., 1993., Outline of Periodontology, 2 nd ed (terj), Hipokrates, Jakarta, 44-6 ; 162

3. Oetojo, I., 2005., Prevalensi dan Keparahan Penyakit Periodontal pada Wanita Hamil Masa Nifas dan Hamil., Majalah PDGI, 3 (45); 50-6

4. Guyton., Halll., 2012., Buku Ajar Fisiologi Kedokteran., EGC, Jakarta, 1284

5. Carranza, F.A., Newman, M.G., 1996., Clinical Periodontology, 8 nd ed., W.B. Saunders Co., Philadelphia, 239-41
6. Carranza, F.A., 2012., Glickman's Clinical Periodontology, $11^{\text {nd }}$ ed., W.B.Saunders Co, Philadelphia, 172-5

7. Sutardjo, A., 2001., Persiapan Persalinan dan Kehamilan yang Aman dan Sehat., J.Kedokteran Gigi, Yogyakarta

8. Apiou, J., Gueguen, M.M., Doleux, S., Bonnauerre-Mallet, M., 2004, Evaluation of a New Toothbrush Concept with Regard to Bacterial Elimination, J. Clin Periodontol., $21: 347-50$

9. Adyatmaka, A., 2008. Buku Pegangan Materi Kesehatan Gigi Mulut Untuk Kegiatan KIA di Posyandu (UKGMD).Departemen Kesehatan RI, 8

10. Sriyono, N.W., Pryono, B.P., Sri Widiati., 2008., Perbedaan Efektifitas Sikat Gigi Konvensional dengan Sikat Gigi Listrik dalam Pembersihan Plak, Laporan Penelitian., FKG., UGM

11. Natamiharja, L., Nimbangsa, G., 1999., Pemilikan dan Pemakaian sikat Gigi masyarakat Kelurahan Beringin Kecamatan Medan Baru, Majalah Kedokteran Gigi USU., Medan., 14; 1-2

12. Van der Weijden, G.A., Timmerman, M.F., 1993., A Comparative Study of Electric Toothbrush for the Effectiveness of Plaque Removal in relation to Toothbrush Duration, Timerstudy, J.Clin Priodontol., 20; 476-81

13. Allen, DL., Mc.Fail, W.T., Hunter, G.C., 2009. Periodontics for The Dental Hygienist, 3 nd ed., Lea and Ferbiger Co., Philadelphia, 170-1, 175-6

14. Dahlan SM, 2011., Statistik Untuk Kedokteran Kesehatan., Salemba Medika, Jakarta, 11-12. 